\title{
Keystones affecting sub-Saharan Africa's prospects for achieving food security through balanced diets ${ }^{\text {th }}$
}

\author{
Julian May \\ School of Government Building, University of the Western Cape, Robert Sobukwe Road, Bellville, Western Cape, South Africa
}

\section{A R T I C L E I N F O}

\section{Keywords:}

Malnutrition

Food systems

Urbanization

Inequality

Nutrition transition

Capabilities

Non-communicable disease

\begin{abstract}
A B S T R A C T
Socio-economic dynamics determine the transition from diets characterized by the risk of famine, to those characterized by the risk of diet-related non-communicable disease (DR-NCD). This transition is of particular concern in Sub-Saharan Africa (SSA) in which key socio-economic interactions that influence diet include economic growth and rapid urbanization; inequality and a growing middle class; and obesogenic food environments and an increasing prevalence of DR-NCD. In each case, countries in SSA are among those experiencing the most rapid change in the world. These interactions, styled as 'keystones', affect the functioning of other components of the food system and the diets that result. Data from the wealthiest quartile of countries in SSA suggest that these keystones may be increasing the risk of DR-NCD, widening inequalities in health outcomes due to unbalanced diets. To address this, new consumer and government capabilities that address these keystones are required. Food sensitive urban planning, supporting food literacy and fiscal management of consumption are examples.
\end{abstract}

\section{Introduction}

Despite a slowing growth rate, the world's population, estimated at 7.3 billion in 2015, is projected to reach around 9.7 billion people in 2050 (UNDESA, 2015a). To adequately feed this increase in population, the chair of the Committee on Food Security asserts, “...in the next 40 years we need to produce more food than we have produced over the last 8000 years" (Sheeran, 2012). Food security scenarios show that this is attainable (van Dijk \& Meijerink, 2014). However as Godfray, Beddington, Crute, Haddad, Lawrence, Muir, et al., (2010: 817) caution, resolving production constraints alone will not be sufficient. Diet, lifestyle, and the accessibility and utilization of food should also be addressed.

Transitions in diet, nutrition, epidemiology and food systems are of relevance throughout the world. Identified drivers include rising incomes, urbanization, trade liberalization and the changing food environment (Kearney, 2010). Although regional differences and dynamics determine whether diets are balanced and sustainable, the focus of the literature is on global trends, trends in developed countries and trends in large developing countries such as China and India (Godfray et al., 2010; Swinburn, Egger, \& Raza, 1999; Pingali, 2007). While there are exceptions such as the Global Nutrition Report (IFRPI, 2016), concern for Sub-Saharan Africa (SSA) tends to emphasize hunger and under-consumption (FAO, 2015; IAASTD, 2009).

Filling this gap is important since diets are changing rapidly in the 48 countries that make up SSA, while opportunities remain to avoid unhealthy and unbalanced diets (Haggblade et al., 2016). ${ }^{1}$ In SSA, the food system is changing within an environment that has the highest projected agricultural production growth rates but also the highest prevalence of food insecurity in the world. The largest amount of population growth and movement will take place in SSA, placing further strain on urban infrastructure, food supply chains and agri-logistic networks (UNDESA, 2015a). Finally the region is likely to experience the greatest variability in climatic and political conditions, including disruptions from conflict, international migration and internally displaced people (FAO, 2012). The diets of these highly vulnerable groups are monotonous, lacking in micronutrients and are often macronutrient deficient (Fayemi, Muchenje, Yetim, \& Abdulatef, 2016).

Even if 'science and good governance' were to succeed in producing more food with fewer inputs (Muchenje \& Mukumbo, 2015), the complexity of food system matters if this accomplishment is to be translated into balanced diets. Van Dijk \& Meijerink (2014: 9) recognize this in

\footnotetext{
Comments received from participants at seminars given at the Institute of Development Research \& Development Policy, Ruhr-Universität Bochum; the Department of Economics at

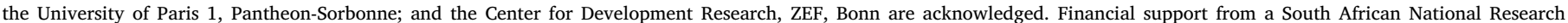

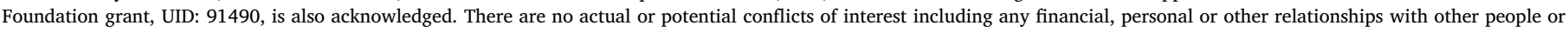
organizations that could inappropriately influence, or be perceived to influence, this work. No human subjects participation was necessary for the preparation of this manuscript.

E-mail address: jmay@uwc.ac.za.

${ }^{1}$ The United Nations Statistics Divisions definition of SSA is adopted (https://unstats.un.org/unsd/methodology/m49/ accessed 31 March 2017).
} 


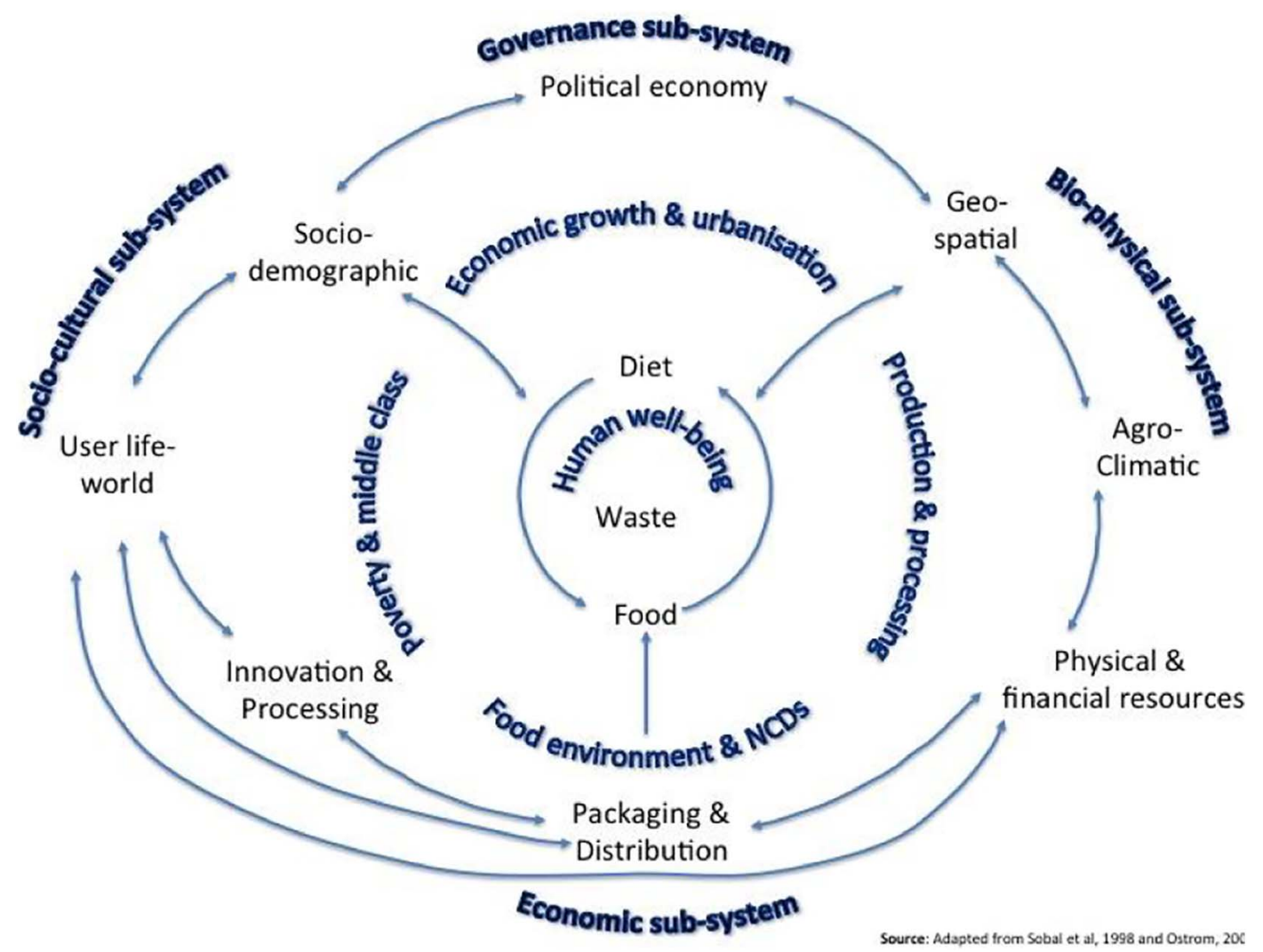

Fig. 1. Onion Diagram of the Food System.

their review of food security scenarios, acknowledging that shifts in diets and consumer preference tend to be superficially treated. With the aim of moving beyond highly aggregated approaches, I focus on SSA's largest economies, adopting a food systems approach to recognize the multi-dimensional nature of food security. The specificities linking the achievement of sustainable and balanced diets to economic and demographic context are explored to reveal the capabilities required by consumers and government to manage food choices and behavior.

\section{Food security, diet and the food system}

Food security is conventionally defined as possessing four dimensions: availability, access, utilization and stability (CFS, 2012). These are hierarchical in nature: food availability is necessary but not sufficient for access; access is necessary but not sufficient for utilization; stability is necessary but not sufficient for utilization (Webb, Coates, Frongillo, Lorge Rogers, Swindale et al., 2006:140). A shortcoming of this approach is that the nature of the food system is given little attention and the linkages between food security, diet, poverty and inequality are opaque. This neglects interactions between the multiple dimensions of food insecurity, differences in the dynamics and terms under which different actors are included into the system, and the impact that both of these might have. Further, resolving a problem conceptualized as 'food security' risks excessive focus on a single dimension: increasing food production and reducing its cost rather than improving its utilization and the diets that result. This underplays the complexity and importance of nutrition security and diet by assigning these to as outcomes from the utilization of food.

Such positions are being challenged and alternative approaches are emerging that focus more strongly on the access and utilization attributes of food security (Akram-Lodhi, 2015; Rocha, 2007; Timmer, 1988; Webb et al., 2006; Wittman et al., 2010:3). Adopting the capabilities approach of Sen's (1980), one response is to highlight food insecurity's connection with poverty and the functionings that follow such as being healthy or being nourished due to being able to access of balanced diet, or being safe by being able to manage food hazards (Barrett, 2010: 825; Timmer, Falcon, and Pearson, 1983:20). Food security can then be regarded as a form of deprivation, and as an outcome of vulnerability (Barrett, 2010:827). From this perspective, food security is 1) multi-dimensional requiring multiple forms of measurement; 2) its intensity and duration will vary; 3 ) it will have an intrahousehold aspect; 4) it has an absolute, subjective and relative nature; and 5) there is culpability for its production, and duty in its reduction (Alkire \& Foster, 2011; Santeramo, 2015a; Hulme \& Shepherd, 2003; Haddad \& Kanbur, 1990; Sen, 1983; Øyen, 2002). As with poverty, food insecurity and the unbalanced diets that result, are caught up in a web of deprivation whose resolution depends upon the systematic relationship between the different forms of deprivation. This web possesses many dimensions that may be difficult to measure, and where the choice of indicators may determine the policy options proposed (Ravallion, 2003; Narayan, Chambers, Kaul Shah, \& Petesch, 2000; Santeramo, 2015b; Webb et al., 2006).

Although what exactly defines a balanced diet remains a subject of debate (Bravata et al., 2003; Schoenaker, Mishra, Callaway, \& Soedamah-Muthu, 2016), a 'triple burden of malnutrition' is recognized that comprises under-nutrition, micronutrient deficiencies and over-nutrition (Pinstrup-Andersen, 2007). Most definitions are thus concerned with the quantity and quality of carbohydrates, protein, fiber and fats, as well as the micronutrients provided by the diet such as minerals, vitamins, and bioactive compounds (FAO, 2010: 219).

The food system is responsible for providing diets that have these attributes. It can be broken down into sub-systems (Sobal, Kettel Khan, \& Bisogni, 1998): chains of “...human-organized activities concerned with the production, processing, transport, selling, cooking and eating of food and the disposal of the wastes of such activities" (Green \& Foster, 2005: 664). These can be represented as episodes taking place in the biophysical, economic, socio-cultural and governance sub-systems of a single food system (see Fig. 1: Onion Diagram of the Food System). 
The activities include the use of physical, financial, agro-climatic and geo-spatial resources to produce food; packaging and distribution networks to convey food; innovation and processing capacity to transform food; the life-world and socio-demographic dynamics of consumers to attach meaning and context to food; and the institutions and processes of political economy to negotiate contestations concerning food. Each requires unique capability sets for the functionings that they involve.

Describing this as a "complex ecosystem" is one attempt to recognize the interaction between human actions and the food system (Drimie, Gillespie, Jere, \& Msuya, 2010; Pollan, 2008). As with any ecosystem, the food system comprises many mutually interacting parts, heterogeneous in their arrangement and characterized by interdependence and symbiotic relationships (von Bertalanffy, 1968:171-196). These are arranged in sub-systems, each with their own networks and dynamics, and further sub-systems (Saaty \& Kearns, 1985: 63-86).

As with other ecosystems, the food ecosystem may be populated by "keystone species" that play a disproportionately large role in the system, and upon which the functioning of other parts of the system may depend (Paine, 1995:963). Plant, animal and bacteria species such as maize, bees or lactobacillus are examples often used in conservation biology (Foster, Krone, \& Forney, 2008; Ze, Duncan, Louis, \& Flint, 2012; Kuhlmann, 2009; Cristancho \& Vining, 2004). This notion has been criticized as being ambiguous in its definition making it difficult to determine what qualifies as being a keystone (Mills, Soule, \& Doak, 1993). Attempts to improve the precision of the concept focus on the impact of the species relative to its abundance, and the uniqueness of its contribution to the functioning of the ecosystem (Kotliar, 2000).

With this clarification in mind, some socio-economic dynamics and institutions provide similar critical processes that shape the operation and outcomes of the food system (Mars, Bronstein, \& Lusch, 2012; Österblom et al., 2015). Such keynotes are figurative and might be institutions and entities such as financial markets, multinational corporations and the strategies adopted by these institutions (Iansiti \& Levien, 2004). Some argue that as the producers, preparers and custodians of the food system, women play a keystone role (Brown, Feldstein, Haddad, \& Peña, 1995). In each case, the removal of these actual species, or their metaphorical equivalents, would likely result in the reconfiguration or even the collapse of the food ecosystem.

Although a food eco-systems approach may reveal the episodes, behavior patterns and potential leverage points involved in ensuring balanced diets, this approach runs the risk of trying to account for all of its components and their multiple interactions. Moreover, using metaphors such as 'keystone species' may distort the intended meaning, and result in appealing, but inappropriate analysis and recommendations for action (Barua, 2011). Mindful of these risks, the lead of Popkin (1999), Hawkes (2006) and Kimenju, Rischke, Klasen, and Qaim (2015) is followed, and three socio-economic dynamics that qualify as keystones relevant to the achievement of balanced diets are selected. These are the interactions of: 1) economic growth and urbanization used in food security forecasting models; 2) inequalities and a growing middle class used in consumption forecasting; and, 3) the changing food environment and the prevalence of diet-related non-communicable disease (DR-NCD) used in epidemiological forecasting (Briggs, Wolstenholme, Blakely, \& Scarborough, 2016). The impact of these interactions is likely to reconfigure the food system in SSA, resulting in diets that are balanced or unbalanced, and ultimately in changes in human well-being.

These interactions are depicted in the third layer of Fig. 1. Although important, production and processing is not considered in this paper, which focuses on socio-economic processes. The objective is to identify policy concerns that move beyond production, market efficiency or food-aid responses to food insecurity, to consider capabilities of consumers and governments necessary to achieve sustainable and balanced diets in SSA.

\section{Data and methods}

Secondary data collated by the World Bank, United Nations Department of Economic and Social Affairs (UN/DESA) and the Food and Agriculture Organization (FAO) is used. Unless otherwise indicated, demographic projections are taken from The World Population Prospects: 2015 Revision (UNDESA, 2015b). The medium fertility variant is used for all population projections.

The World Development Indicators (WDI) for 2014 updated on 10 August 2016 and accessed on 13 August 2016, have been used for all socio-economic indicators reported. Production data have been taken from various databases within FAOSTAT using the January 19, 2017 update accessed on 22 January 2017.

Gross National Income (GNI) for 2014 has been used as the preferred indicator of economic prosperity. GNI for 2011 has been used for 16 SSA countries, including Angola, Cote d'Ivoire and Zambia. While acknowledging the progress made by official statistics agencies in SSA, the reservations of Jerven (2013) regarding data quality must be kept in mind. As a result, Gross Domestic Product (GDP) has been used for historical trends. All GNI, GDP and income data are provided in current international dollars (Purchasing Power Parity - PPP) based on the 2011 International Comparison Program estimates.

The 12 largest economies in terms of GNI have been selected. These are Angola, Cameroon, Côte d'Ivoire, Democratic Republic of the Congo (DRC), Ethiopia, Ghana, Kenya, Nigeria, South Africa, Uganda, United Republic of Tanzania and Zambia. Henceforth these are referred to as the SSA 12.

\section{Food security trends in SSA}

Various attempts have been made to assess the sustainability of the food system, and its capacity to feed the global population. Agrimonde (2009) is one of the most recent and comprehensive. Agrimonde is based on a detailed analysis of food production trends from 1961 until 2003 using FAO data and econometric modeling to predict two possible scenarios to 2050 . The data are concerned with food availability and focus mainly on trends in human population; the use of food products; land use patterns; food production and yield; and net food trade.

The point of departure for Agrimonde is that the level of future food consumption will depend upon population change and the growth of economic output per capita (Paillard, Treyer, \& Dorin, 2014). The scenarios are useful point of departure for further debate concerning their implications at the regional level. In addition to providing direct information on the availability of food, these scenarios are also important because they signal a likely nutrition transition before 2050 in which in dietary patterns and nutrient intakes will also change. These nutrition and epidemiological changes are occurring at a rapid rate in SSA, as well as at earlier stages of economic and social development (Popkin \& Gordon-Larsen, 2004).

Although levels remain low, recent food security trends appear to be positive in SSA. While food production in SSA traditionally lagged that of the rest of the world, since 2005, the FAO's Food Production Index for SSA has been similar, or greater than that for the rest of the world. Food availability in Sub-Saharan Africa has increased by nearly $12 \%$ over the past two decades. In the case of the SSA 12, in 2014, only DRC, Nigeria and Uganda have indices lower than that for the rest of the world.

As for food outcomes, the global trend is towards decreasing undernutrition. This has occurred in SSA and prevalence of under-nutrition (having a level of food intake that is insufficient to meet dietary energy requirements) declined from $33 \%$ to $23.2 \%$ between 1990 and 92 and 2014-16. ${ }^{2}$ Nonetheless, the total number of undernourished people has

\footnotetext{
${ }^{2}$ The indicator is derived from food balance sheets, and is the product of a regression model estimating the probability of consuming less than the dietary energy requirement
} 


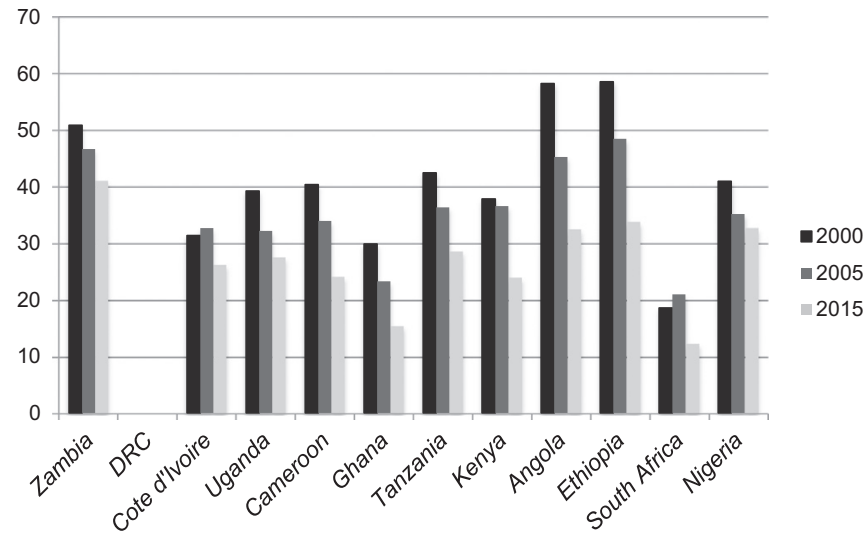

Fig. 2. Global Hunger Index Score Source: IFPRI, 2016.

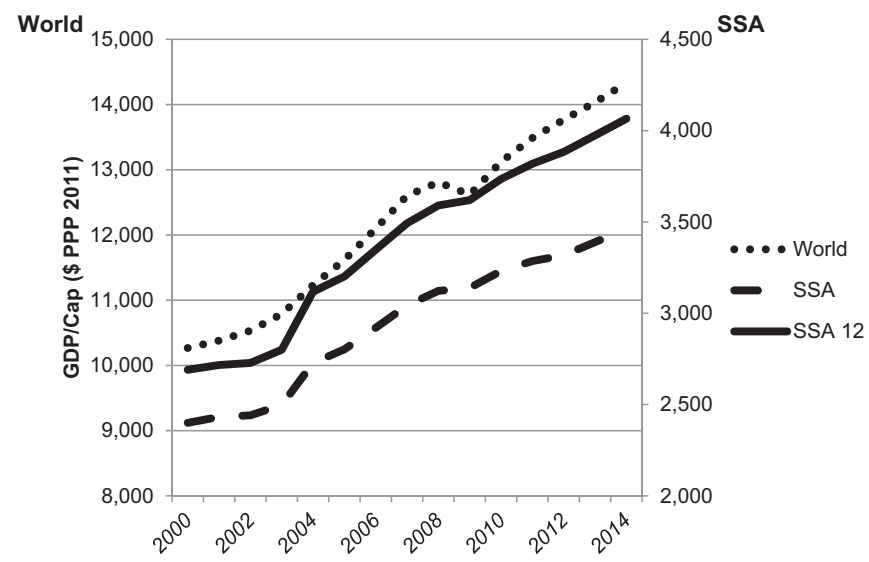

Fig. 3. Growth in GDP per capita

Source: WDI, 2016.

continued to increase with an estimated 220 million in 2014-16 compared to 175.7 million in 1990-92 and SSA has the second largest share of the world's undernourished people after Southeast Asia and the highest prevalence. Projections by the USDA show that this situation is expected to improve the next 10 years, although at a slower rate than that of other regions. According to this model, the share of the region's population that is food insecure is projected to fall from its current $29 \%$ to $15 \%$ by 2026 (Rosen, Thome, \& Meade, 2016).

There are regional differences with the number doubling and the prevalence of undernourishment increasing in Central Africa from $33.5 \%$ in $1990-92$ to $41.3 \%$ in $2014-16$, while Western Africa has experienced the greatest decrease in the same period, from $24.2 \%$ to 9.6\% (FAO, IFAD and WFP, 2015). There are also differences when alternative measures of undernourishment are used. For example, describing their food status, just one-fifth of urban Africans self-report being deprived of an adequate amount of food: a prevalence that is well below the poverty headcount of most countries (Afro-barometer, 2015).

The Global Hunger Index Score (GHI) calculated by the International Food Policy Research Institute (IFPRI, 2016) and shown in Fig. 2 shows these trends for the SSA $12 .^{3}$

All countries experienced a decline in the score, with declines being particularly notable in Ghana, Angola and Ethiopia. South Africa is the only country to have experienced an increase in 2005.

Direct measures of dietary outcomes follow these trends, although with more modest change. The number of underweight children in SSA

(footnote continued)

(DER).

${ }^{3}$ The GHI does not report figures for the DRC. has declined over the last two decades from $28.5 \%$ in $1990-92$ to $21.1 \%$ in 2014-16. Stunting (being under the expected height for age) has reduced only marginally from $41 \%$ of under-five year old children in 1990 to $35.0 \%$ in 2012 (FAO, IFAD, \& WFP, 2015; FAO, 2015; WHO, 2014). Greater progress has been achieved in some SSA 12 countries. In Ethiopia the prevalence of stunting fell from $57 \%$ in 2000 to $44 \%$ in 2011 , and in Ghana stunting has fallen from $35 \%$ in 2003 to $28 \%$ in 2011. South Africa has experienced only a slight improvement, from $30 \%$ in 1993 to $27 \%$ in 2016 (Stats, 2017), reflecting the puzzling persistence of poor child outcomes despite an extensive social protection program and public health policies that target children (Devereux \& Waidler, 2017).

\section{Keystones to achieve food security with a balanced diet}

\subsection{Keystone 1: Economic growth and urbanization}

Rapid economic and population growth are among the most significant megatrends affecting food security and diet (Gandhi \& Zhou, 2014). This is a potentially endogenous relationship since food security also affects economic growth. If an economy produces insufficient food, its expansion will increase the demand for food. If food demanded cannot be imported at an accessible and stable price, this may translate into higher wage demands, widening inequalities, reducing investment and thus slowing growth (Timmer, 1988).

There has been a period of comparative prosperity in SSA since 2000 . The combined GNI of SSA was $\$ 3258$ billion in 2014, more than double the level in 2000. The wealthiest quintile of countries, the SSA 12 , is home to $69 \%$ of the population of the region and contributes $82 \%$ of the GNI, and $78 \%$ of GDP. These economies have experienced consistent growth in per capita GDP, shown in Fig. $3,{ }^{4}$ at a time when the growth of most developed economies has been sluggish.

The comparative population size and GNI of the SSA 12, shown in Fig. 4, reveals the significant differences between these countries. Although Nigeria and South Africa dominate in terms of the size of their economies, Ethiopia and Kenya, Tanzania and Ghana have grown in terms of their share of total GNI of SSA.

While the Nigerian economy is estimated to be larger than the South African, South Africa's GNI per capita $(\$ 12,113)$ is more than double that of Nigeria (\$5443), and three times that of Ghana and Cameroon. In contrast, despite being one of the SSA 12, the DRC is one of the poorest countries in the world due to the size of its population.

The total population of SSA, estimated to be 962 million in 2015, experienced an increase of almost $50 \%$ or 320 million people from 2000. This is the fastest rate of change of all regions (UNDESA, 2015a). By 2050, the region is expected to accommodate 2.1 billion people, a dramatic increase in its share of the global population that currently stands at $13 \%$ to over $21 \%$. Half of the increase in population will be in five countries: Nigeria, Ethiopia, DRC, Tanzania and Uganda. This population growth is not simply due to high levels of fertility. Most countries are experiencing a decline in the number of children born per woman of reproductive age. Other drivers of population growth are important including a decline in infant mortality and increasing longevity.

Although rural population of SSA will continue to grow, much of the expansion in population numbers is set to occur in urban areas. At 359 million people, the urban population in SSA accounted for $37.5 \%$ of the region's population in 2015, but is expected to reach 1.1 billion by 2050. This will then account for just over half of the total population of SSA, and almost one third of the world's urban population. This means that SSA will have the second largest number of urban dwellers after Asia. Further, $74 \%$ of the urban population of SSA is younger than

\footnotetext{
${ }^{4}$ Note that the primary and secondary axes differ in order to reflect the smaller absolute GDP/per capita in SSA.
} 


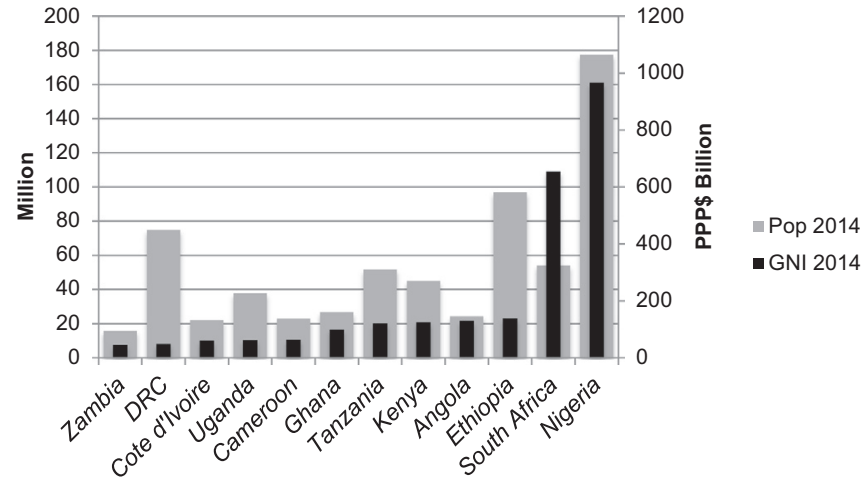

Fig. 4. Population and economy 2014

Source: WDI, 2016.

35 years of age: the highest proportion, and fastest growing in the world.

Just over $27 \%$ of this urban population will be living in Nigeria alone, concentrated in Lagos which currently has a population of 12.6 million (UNDESA, 2014: 217). Kinshasa became SSA's second mega-city in 2015 with a population of 10.2 million while Dar es Salaam, Johannesburg and Luanda are expected to grow beyond 10 million by 2030 (UNDESA, 2014: 20).

Urban population growth is not confined only to the capital cities of SSA. One quarter of the 100 fastest-growing cities in the world are located in Africa, and in 2011, 52 cities on the continent had more than one million inhabitants which is expected to increase to 94 cities by 2030 (Mo Ibrahim Foundation, 2015). In addition to these secondary cities, small towns are also growing in size and in number (AfDB, OECD, \& UNDP, 2016: 159). Fig. 5 provides the actual and projected growth of urban settlements, and shows that by 2050 about $40 \%$ of the urban population is expected to be living in cities of one million people or less.

There are significant differences between countries. In Ethiopia 83\% of the urban population live in secondary cities and towns of less than 0.5 million people in 2015. This can be compared to Angola where $55 \%$ of the urban population live in Luanda, which has a population of over 5 million, and just 33\% live in towns of less than 0.5 million.

Rural to urban migration accounts for about one third of the population growth of SSA's cities. However urbanization does not necessarily imply poverty reduction, and can mean the transfer of people who are poor from rural to urban areas. Urbanization does also not necessarily arise from, or result in economic growth. This has been the case in some countries of SSA, such as Cameroon and the DRC

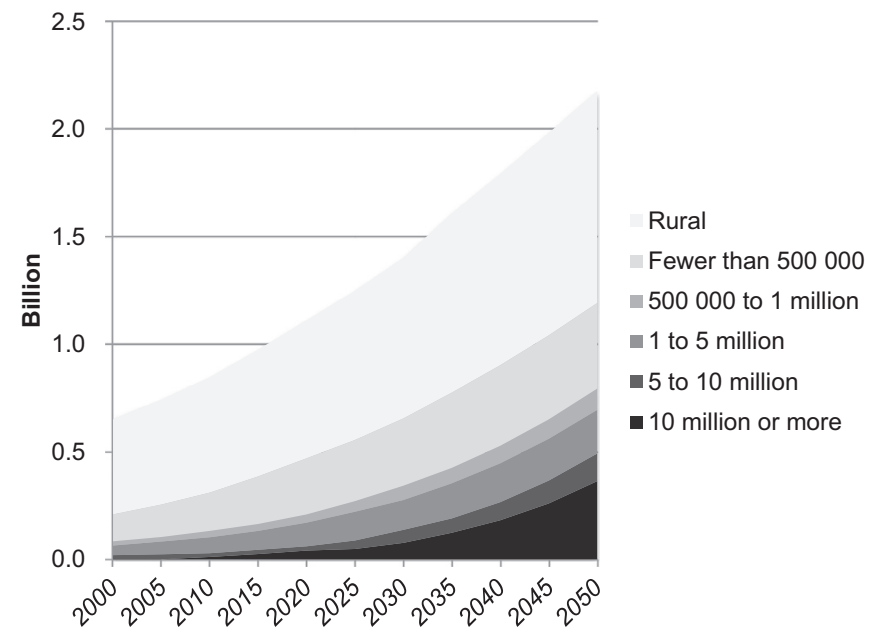

Fig. 5. Population projection of settlement type: 2000-2050 Source: UNDESA, 2014.
(UNDESA, 2014; Mo Ibrahim Foundation, 2015). Urbanization has also not been accompanied by industrialization, which has declined in relative importance in most SSA countries.

Further such migration is not necessarily permanent. Insecure access to employment and poor living conditions has also resulted in a counter-urbanization movement and patterns of circular migration (Potts, 2013:9). This trend, evident in Zambia and Cote d'Ivoire, places further pressure on the production of food. Unless protected and absorbed into the urban fabric, arable land near to cities will be converted to informal settlements, while land in rural communities may be underutilized due to a shortage of labor at critical times.

Managing the interaction between the economic growth and urbanization trends that have been depicted will require new capabilities for all aspects of the planning and habitation of cities, including those needed for food security. In some cases where cities have experienced a construction boom and rapidly rising housing prices, urban planning that takes account of food provision and foodways might be feasible. However in many cases new construction has not been sufficient to absorb the inflow and expansion takes place in unregulated, poorly serviced informal settlements. In 2014, 55\% of the urban population of SSA was living in such settlements, ranging from three quarters of the urban populations of the DRC and Ethiopia to $23 \%$ for South Africa (UN-HABITAT, 2014; WDI, 2016). ${ }^{5}$

As a further hindrance to the attainment of food security, economic growth and urbanization place pressure on basic services. In SSA, 17\% of the urban population lack access to improved drinking water, $26 \%$ are without improved sanitation, and 39\% of those with improved sanitation have access only to facilities shared with other households, and open defecation is practiced by $9 \%$ (WHO \& UNICEF, 2014). As with other indicators, the situation varies across SSA, and in Kinshasa, 81\% of the urban population lack access to improved drinking water while up to $90 \%$ of the natural springs in the city are thought to be contaminated (UNEP, 2010: 217). Even in Ghana, one of the fastest growing economies in SSA, only $13 \%$ of the population is using improved sanitation and open defecation is practiced by an estimated $20 \%$ of the population (UNEP, 2010: 249).

Poor water, sanitation and hygiene (WASH) practices increase the risk of enteric infections, the array of bacterial, parasitic, and viral pathogens that result in diarrhea. Ingestion of feces and soil contribute to this risk in polluted environments such as dense shack settlements where human overcrowding and animals are present. This is reflected in the rate of diarrhea episodes per person per year in SSA, which is the highest in the world at 1.29 compared to the global average of 0.75 (Hutton \& Haller, 2004).

Poor WASH also increases the risks associated with food safety hazards, especially when combined with the impact of climate change and the variability of water supply (Tirado, Clarke, Jaykus, McQuattersGollop, \& Frank, 2010). Lastly, chronic and repeated microbial infections have been linked to environmental enteropathy, reducing the bioavailability of nutrients from food that has been consumed (Chambers \& von Medeazza, 2014; Brown et al., 2015). Recognizing this, the Global Nutrition Report draws attention to the need for nutrition sensitive WASH capabilities (IFPRI, 2016: 70).

Diet and the utilization patterns of food are also affected by the availability of energy in urban areas. In SSA, by 2014 almost $72 \%$ of the urban population had access to electricity compared to $15.2 \%$ of the rural population. The African Development Bank (AfDB) expects that the demand for power will continue to increase, almost doubling between 2015 and 2035 (AfDB, 2014).

Access to electricity can increase the shelf life of perishable food, reduce food hazards, and reduce the drudgery of food preparation and disposal. However access to electricity also has the potential to change

\footnotetext{
${ }^{5}$ WDI make use of a durability and services definition to identify the population living in slums.
} 


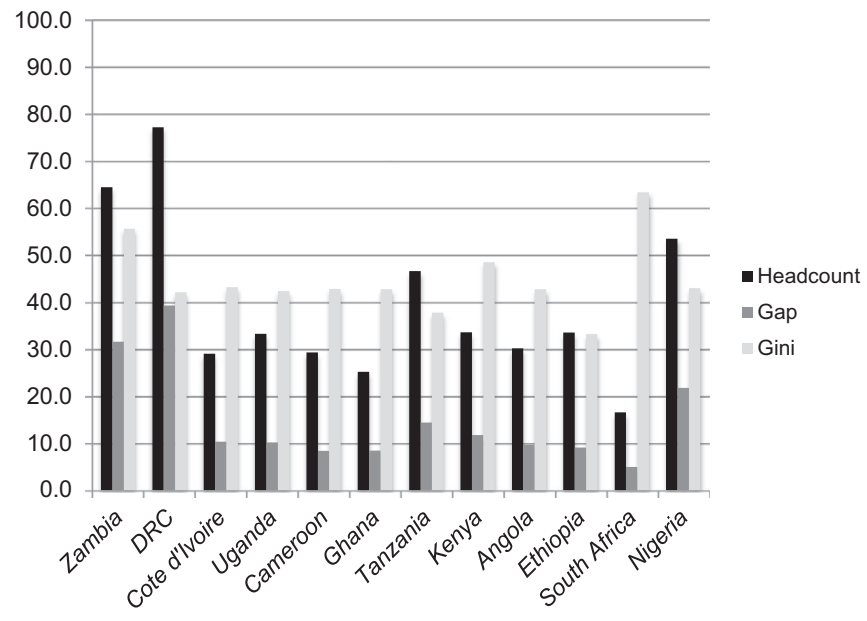

Fig. 6. Poverty headcount and gap*

*The Headcount reflects the percentage of the total population below the international poverty line. The Gap reflects the average of the poverty gap to the poverty line expressed as a percentage. The Gini coefficient is a measure of income inequality in which 0 is perfect equality and 100 is perfect inequality.

Source: WDI, 2016.

consumption patterns, and may result in diets that include the greater consumption of processed food and beverages that contain high levels of salt, sugar and undesirable fats, a point that will be expanded below (Popkin, 2001). Government, especially municipal government, will need the capability to distribute, maintain and collect payment for this electricity when it is provided, while consumers will need the capability to manage their use of this service.

\subsection{Keystone 2: Inequality and a growing middle class}

One of the pathways through which economic growth and urbanization impact diets are through increased incomes and rising inequality. The rise in the average per capita incomes of many countries previously classified as being low-income countries meant that more countries have graduated into middle-income status. Between 1993 and 2011 the poverty rate of SSA declined by $23 \%$ and concomitantly, there has been the increase of what Ncube, Lufumpa, and Kayizzi-Mugerwa (2011) refer to as a "floating class", and Hulme and Shepherd (2003) as the "churning poor": above the poverty line but highly vulnerable. The poverty levels for the SSA 12 are shown in Fig. 6, along with the Gini coefficient, a measure of inequality.

The DRC and Zambia have the largest share of their populations below the international poverty line of $\$ 1.90$ per person per day, and have the greatest poverty gap (the depth of poverty measured as the average distance below the poverty line). Despite its comparative wealth, South Africa's headcount and poverty gap remain high at $16.6 \%$ of the population, and $4.9 \%$ of the poverty line respectively. Divergence between apparent economic wealth and household poverty is even more apparent for Nigeria in which the headcount and gap are 53.5 and $21.8 \%$ respectively. These patterns are reflected in the measure of inequality with South Africa being the most unequal, followed by Zambia and Nigeria.

An outcome from this keystone of significance to diet has been a growing class of medium and high spenders in SSA along with the more modest decline in poverty levels (WDI, 2016; Ncube et al., 2011). Estimates by the African Development Bank (AfDB) of the size of the middle class in Africa (not just SSA) are 327-355 million in 2010, or $34 \%$ of the population and projected to reach 1.1 billion by 2060 (Ncube et al., 2011). The AfDB estimates that consumer spending by the middle class amounted to almost one quarter of the continent's GDP. The definition of this group is generous: those with per capita daily consumption level of $\$ 2-20$. At the lower end of the scale, 180 million people are included who are highly vulnerable to becoming poor. This has led some analysts to suggest that further significant growth in SSA's middle class is likely to be limited and that further economic growth will widen inequalities (Potts, 2013). Tschirley, Reardon, Dolislager, and Snyder (2015) show that the impact of economic growth in SSA has been mixed, having reduced, maintained and widened inequality, and that average incomes have increased in all income groups.

Although there is a substantial literature exploring how changes in income affect consumption choices, reviews suggest that the results are ambiguous (Haddad, Alderman, Appleton, Song, \& Yohannes, 2003; Santeramo \& Shabnam, 2015c). Some authorities contend that rising incomes increase the consumption of calories, a positive result when there is a high prevalence of caloric poverty. In other contexts, there is evidence that the income elasticity of calorie consumption may be close to zero (Bouis \& Haddad, 1992; Subramanian \& Deaton, 1996).

It is not only calorie consumption that is uncertain. Bennett's law holds that rising incomes are associated with increased consumption of animal proteins, the decline of starchy staples and greater dietary diversity (Bennett, 1954). This is confirmed by analysis of both the 1995 and 2005 rounds of the International Comparison Program, which shows that consumers in low income countries make larger adjustments to their food consumption patterns than those in middle and high income countries when incomes and prices change (Muhammad, Seale, Meade, \& Regmi, 2011). These adjustments vary with changes being smaller for staple food consumption than for other food categories, and with households in higher income countries being more likely to spend more on nutritious food (Melo et al., 2015).

Ruel, Minot, and Smith (2005) confirm these patterns for SSA but also show that the pace is too slow to achieve desired levels of consumption of foods necessary for a balanced diet, notably fruit and vegetables. Barrett and Bevis (2015) go further to suggest that micronutrient intake does not increase at the same rate as macronutrient intake. Claro and Monteiro (2010) present evidence from Brazil that support this, showing that the demand for healthy foods such as fruit and vegetables is comparatively inelastic in both urban and rural contexts and does not increase as incomes rise. Darmon and Drewnowski (2015) show that while the cost of a healthy diet is rising, the cost of unhealthy diets that contain processed foods with excessive fat, salt and sugar and little nutrient value is declining. The higher costs of healthy diets is supported by the systematic review of Rao, Afshin, Singh, and Mozaffarian (2013) and suggest that these trends are also emerging in newly graduated middle-income countries.

There are several implications that follow. While rising incomes could result in more diverse, and more balanced diets, it is also possible that food that is less healthy may be chosen, both due to preference as well as to its cost. Further, food choices will be affected by income and price shocks to the household. These may be idiosyncratic such as the loss of employment or injury, covariant such as surges in food prices or economic crisis, or the result of life cycle events such as births or retirement from the labor market.

Coping strategies to respond to such shocks affecting economic access to food include reducing consumption; switching to cheaper sources of food energy and decreasing consumption of potentially nourishing non-staple foods (Ruel, Garrett, Hawkes, \& Cohen, 2010). Each of these has an intra-household dimension in which some members of the household, notably women, may sacrifice their food quantity or quality to ensure that other members are not affected. The long-term consequences of such coping strategies can be severe, especially those that affect maternal health.

For the SSA 12, the differences between national economic prosperity and the levels of income inequality shown above mean that these dynamics will vary by country, as well as between households. For example, for those in the bottom quintile in South Africa where the nutrition transition is largely complete, it seems likely that a decline in the ability to access food would result in a shift to cheaper, processed and potentially unhealthy food consumed away from the home (Neil, 
Rulof, Wicus, \& Friedrich, 2015; Igumbor et al., 2012). In Nigeria, such a decline may result in a decline in the consumption of meat and an increase in the consumption of grains and tubers (Zhou \& Staatz, 2016).

In addition to the capabilities required to protect livelihoods, managing household diets in times of economic stress without access to subsistence agriculture emerges as an important capability for SSA's urbanizing population. Rising incomes present governments with opportunities to manage this keystone. Redistributive policies such as social protection to transfer resources to the food insecure are an option to manage the impact of shocks and life-course events. Policies to manage behavior include selective food taxes and rebates such as the sugar tax proposed for South Africa (Government of South Africa, 2016; Brownell \& Frieden, 2009). In the context of SSA, many governments will need to improve their capability to design, implement and enforce such policies. They will also need to develop appropriate tools with which to measure the impact of these policies on food and nutritional insecurity (Santeramo, 2015a).

\subsection{Keystone 3: Obesogenic food environments and non-communicable disease}

For diets, the implications of economic growth, urbanization, inequality and rising incomes are complex. As already discussed, as income rise, a nutrition transition takes place towards diets that emphasize convenience and reduced preparation time, and which contain more energy-dense processed foods and foods that are high in saturated and trans-fats, sugars, salt and cholesterol relative to their nutritional value (Popkin, 2003). This has been accompanied by an increase in the numbers who are overweight or obese and increasing numbers of younger people being over-weight or obese, and prone to DR-NCD (Ng et al., 2014). This results in an epidemiological transition with a shift from a backlog of common infections, under-nutrition, and maternal mortality, towards NCDs such as cancer, diabetes, heart disease, and mental illness, and health challenges directly related to globalization, such as pandemics and the health consequences of climate change (Frenk \& Gómez-Dantés, 2011).

Although urban consumers spend a smaller share of their income on food than those living in rural areas, about half of the expenditure of poor urban households in SSA is still made on food, and the bulk of food consumed is purchased (Frayne et al., 2010). Urban consumers purchase more food products that are highly processed, and which contain ingredients that are imported; they consume more animal protein and dairy; and they are more likely to be affected by, and to respond to changes in global prices and preferences (Gómez \& Ricketts, 2013; Tschirley et al., 2015; Nakamura et al., 2016).

With urbanization and rising per capita incomes, obesogenic food environments are developing in SSA (Hawkes, 2006; Igumbor et al., 2012). Consumers show greater selectivity in the products that they consume, choosing to discard parts of animals (such as the offal and hooves) and plants (such as the stalks and leaves) that may be nutritious but are less preferred. Urban consumers are also more likely to prefer convenience foods that require less time to prepare and increase their consumption of caloric sweeteners, especially from aerated beverages. Finally, 70\% of urban households in SSA purchase from vendors in the informal economy and a significant share of this expenditure is on prepared food. Some of this consumption is of minimally processed such as boiled maize cobs or grilled offal. Increasingly, it includes unhealthy processed foods with a high fat, sugar and salt content (Frayne et al., 2010; Battersby \& McLachlan, 2013).

The achievement of balanced diets is strongly shaped by what is provided in the shelves and baskets of distributors in the formal and informal economy, and what eventually materializes on the plates of those who consume the food. The Agrimonde scenarios recognize that this has a critical impact on the food system as a whole. An important assumption of the scenarios is whether the plates of all regions in the world will converge towards providing an average consumption of

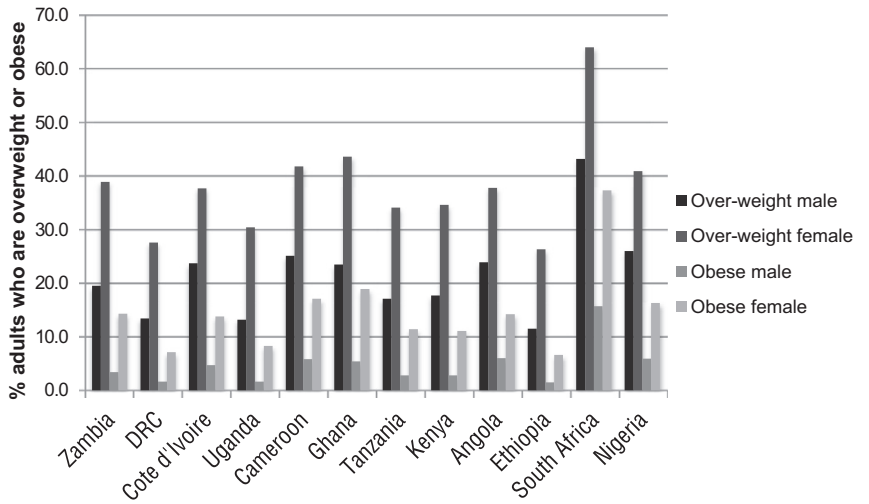

Fig. 7. Overweight and obesity Source: IFPRI, 2016.

$3000 \mathrm{kcal}$ per person per day. Very different outcomes are likely if prevailing trends of inequality continue as opposed to convergence at this level, which will both reduce under-nutrition and limit over-nutrition. A food ecosystem that is obesogenic, containing stimuli that encourage over-consumption, will have the opposite effect (Swinburn et al., 1999).

The latter scenario of widening inequality seems likely. There has been an increase in the numbers and share of people who are overweight and obese. Globally, 1.3 billion adults in the world are overweight, and of this group, 400 million are obese. By 2030, there could be 3 billion overweight and 1 billion obese people (Kelly, Yang, Chen, Reynolds, \& He, 2008), and by 2050 half the world's population could be overweight or obese (Dobbs \& Manyika, 2015). In SSA, 30\% of the adult population is overweight or obese, and 6\% are obese (WHO, 2014). Overweight is also on the rise among children below five years and in the adolescent group, especially among girls. As is shown in Figs. 7 and 8, there is considerable variation between men and women in the SSA 12, and between different levels of economic wealth for all SSA counties.

The trend line fitted to Fig. 8 shows that higher levels of GNI per capita are associated with a higher prevalence of female overweight in SSA, a pattern that has been observed globally (FAO, 2002). South Africa (circled) has the highest prevalence at $64 \%$ of adult women. The other countries with extremely high prevalence and high GNI per capita are Seychelles (63\%) and Botswana (59\%). These countries also have relatively high inequality.

South Africa is illustrative as to how changes in the diets of other SSA countries might unfold. Whereas seven million South Africans still experience chronic or more severe hunger, 21 million people are overweight or obese. Over the past fifty years fat intakes among the bulk of the population have increased from $16 \%$ to $26 \%$ of total energy while carbohydrate intakes have decreased from $69 \%$ to $62 \%$ of total

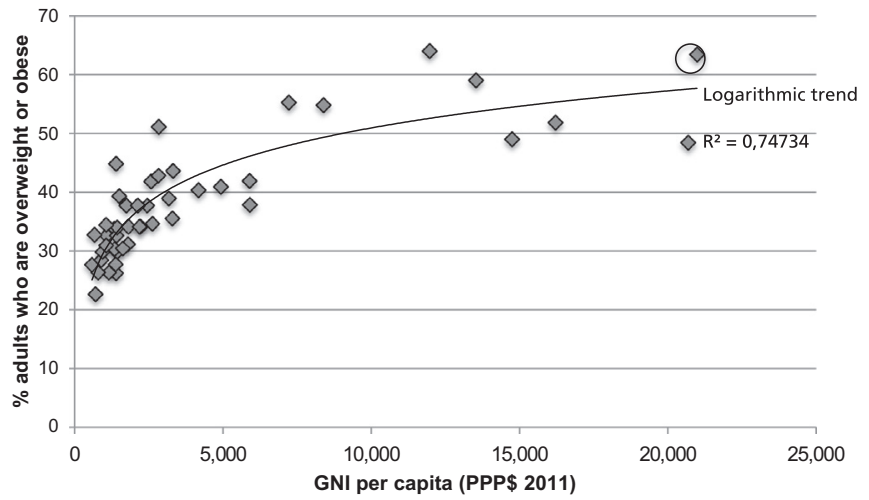

Fig. 8. Overweight by Gross National Income (GNI) Source: WDI, 2016; IFPRI, 2016. 
energy in the past 50 years (Bourne, Lambert, \& Steyn, 2002). This is compounded by a salt intake that is in excess of recommended levels (Hofman \& Tollman, 2013). The consumption of caloric beverages is a further component of this. Compared with a worldwide average of 89 , in 2010 South Africans consumed 254 cola products per person per year, an increase from around 130 in 1992. In 2010, up to half of young people were reported to consume fast foods, cakes and biscuits, cold drinks, and sweets at least four days a week (Igumbor et al., 2012). Carbonated drinks are now the third most commonly consumed food/ drink item among urban South African children aged 12-24 months; less frequently consumed than the staple, maize meal, but more often than milk (Stats, 2012). These unbalanced diets may be part of the explanation for the poor progress in child stunting discussed earlier.

These trends are emerging elsewhere in SSA with indications of a triple burden in increasing numbers of countries (Abrahams, Mchiza, \& Steyn, 2011). Cereal consumption is growing in almost all countries, with an average rate of $2 \%$ per decade between 1981 and 2007, and with Ghana growing the fastest at $13 \%$ per decade (Chauvin, Mulangu, \& Porto, 2012: 34). The African Prosperity Report links the rise of an African middle class to expanded opportunities in the fast food industry (Legatum Institute, 2016). With a presence in Angola, Ghana, Kenya, Nigeria, South Africa, Tanzania and Uganda, and plans to enter the DRC, KFC generated $\$ 2$ billion in sales from more than $1000 \mathrm{KFCs}$ across the continent in 2014. Adapting to local preferences, outlets also sell fish burgers, jollof rice (vegetable fried rice) and nshima (maize meal) in addition to the ubiquitous fried chicken (Kay, 2014). Kilimanjaro, a Nigerian owned competitor currently with 24 outlets, sells pounded yam, edikaikong (a local soup) and a catfish combo meal. The aerated beverage market is also growing. Based in South Africa, the recently established Coca-Cola Beverages Africa Company will operate in eight of the SSA 12 to produce and distribute $40 \%$ of all Coca-Cola beverage volumes on the continent. This plant is the 10th largest CocaCola bottler worldwide. ${ }^{6}$

The availability of these products can exacerbate the triple challenge of malnutrition discussed above. This goes beyond inequalities in the access to food to encompass inequalities in capabilities required to effectively utilize food that result in unbalanced diets with poor health outcomes arising from DR-NCD (Burchi \& De Muro, 2016; Vincent, Vincent, \& Lamb, 2010).

Globally, diabetes accounts for second largest share of the global burden of DR-NCDs after ischemic heart disease. This is set to increase and the prevalence of diabetes among all age groups worldwide, estimated to be $2.8 \%$ in 2000 , is expected to rise to $4.4 \%$ by 2030 , increasing the total number of people with diabetes from 171 million in 2000 to 366 million in 2030 (IDF, 2015; Wild, Roglic, Green, Sicree, \& King, 2004). The costs associated with diabetes are estimated to mushroom worldwide by between $\$ 213$ and 396 billion a year by 2025 (Björk, 2004).

This is also the case in SSA. In 2000, an estimated 14 million adults aged 20-79 had diabetes in Africa, representing a regional prevalence of $2.1-6.7 \%$. This is projected to reach $18.6 \%$ in 2030 , an increase of $162 \%$, and the second greatest increase after the Middle East (Wild et al., 2004). Notably, $59 \%$ of people with diabetes are in urban areas. The region also has the highest proportion of undiagnosed diabetes with over two thirds of those living with diabetes are unaware they have the disease. There is variation between and within countries. While the prevalence of diabetes in Ethiopia is only $2 \%$, in some age groups and some contexts, it is much higher. Less than half of those diagnosed with diabetes in Ethiopia are receiving standard diabetes care (Haregu, 2012).

\footnotetext{
${ }^{6}$ Accessed from https://kfc.co.za/ourstory/news/kfc-announces-the-opening-of-its1000th-restaurant-in-sub-saharan-africa; http://kilimanjaro-restaurants.com/; http:// www.coca-colacompany.com/press-center/press-releases/coca-cola-beverages-africabegins-operations, 28/03/17, respectively.
}

Similar trends are been found with respect to other DR-NCDs, with for example, the prevalence of cardiovascular disease increasing in SSA (Opie \& Mayosi, 2005). In Ghana, hypertension, stroke and diabetes are now listed as among the top ten causes of death (Aikins, Addo, Ofei, Bosu, \& Agyemang, 2012). Similar increases in prevalence are reported in neighboring Cameroon among the other SSA 12, while projections from the Global Burden of Disease Project estimate that from 1990 to 2020, the burden of cardiovascular disease in SSA will double (Tantchou Tchoumi \& Butera, 2013; Mbewu \& Mbanya, 2006).

Despite these disturbing trends and their likely economic costs (Popkin, Horton, Kim, Mahal, \& Shuigao, 2001), the policy response in SSA is muted. For example, public expenditure on diabetes healthcare in SSA is the lowest in the world, amounting to 7\% of the region's total health budget (IDF, 2015). Few countries provide adequate coverage of drugs for cardiovascular disorders (Mocumbi, 2012). Although consumers may not have access to the information required to make healthy food choices in the face of unregulated demand management by food producers and retailers, few countries are attempting to regulate such advertising although this has been shown to impact on food choices (Vukmirovic, 2015). This leaves a potential policy and capability lacuna in SSA in the face of emerging obesogenic food environments.

\section{Conclusion}

Changes in income, location, access to services and access to information are associated with changes in the prevalence of DR-NCDs. In SSA, trends in DR-NCDs have not been matched by increased resource allocations for their management. More than additional resources are required: also essential are the development of nutrition-sensitive capabilities for food security often neglected in policy interventions for food security. These include consumer capabilities needed to make good use of food, including being food literate, being able to adopt safe food practices, and being able to make healthy diet and lifestyle choices. Appropriate food preparation practices in environments prone to food safety hazards are necessary, while taking advantage of opportunities provided by urban environments is also important. New capabilities are also required for the public and private sectors, including being able to enforce and ensure adherence to regulations pertaining to advertising, labeling, traceability, supplementation, fortification and food safety management; being able to manage the avoidance and treatment of DR-NCDs; being able adopt food sensitive fiscal and urban planning to manage food demand; and being able to introduce and finance social protection programs. Diagnostics for the design and targeting of specific interventions, and quantifying their impact will require the development of new capabilities in official statistics agencies responsible for the measurement of the multi-dimensional nature of food insecurity. Nutrition sensitive food systems are still possible in SSA, and building such capabilities can ensure that food security is achieved through balanced diets.

\section{References}

Abrahams, Z., Mchiza, Z., \& Steyn, N. P. (2011). Diet and mortality rates in sub-Saharan Africa: Stages in the nutrition transition. BMC Public Health, 11(1), 801.

AfDB, OECD \& UNDP (2016). African economic outlook 2016 sustainable cities and structural transformation. African development bank, organization for economic co-operation and developmentTunis: United Nations Development Programme (Retrieved from http://www.africaneconomicoutlook.org/en/theme/sustainable-cities-andstructural-transformation, 31 March, 2017.).

AfDB (2014). Tracing Africa's progress in figures. Tunis: African Development Bank Retrieved from https://www.afdb.org/en/knowledge/publications/tracking-africa\% E2\%80\%99s-progress-in-figures/, 31 March, 2017.

Afro-barometer (2015). Afro-barometer database. (Retrieved from www.afrobarometer. org/data, 23 February 2016).

Agrimonde (2009). Scenarios and challenges for feeding the world in 2050: Summary report. Montpellier and Paris: CIRAD and INRA.

Akram-Lodhi, A. H. (2015). Accelerating towards food sovereignty. Third World Quarterly, 36(3), 563-583. 
Alkire, S., \& Foster, J. (2011). Counting and multidimensional poverty measurement. Journal of Public Economics, 95(7), 476-487.

Aikins, A. D. G., Addo, J., Ofei, F., Bosu, W. K., \& Agyemang, C. (2012). Ghana's burden of chronic non-communicable diseases: Future directions in research, practice and policy. Ghana Medical Journal, 46(2 Suppl), 1.

Barrett, C. (2010). Measuring food insecurity. Science, 327, 825-828. http://dx.doi.org/ $10.1126 /$ science. 1182768 .

Barrett, C. B., \& Bevis, L. E. (2015). The micronutrient deficiencies challenge in African food systems. The fight against hunger and malnutrition: The role of food, agriculture, and targeted policies (pp. 61-88). Oxford: Oxford University Press.

Barua, M. (2011). Mobilizing metaphors: The popular use of keystone, flagship and umbrella species concepts. Biodiversity and Conservation, 20(7), 1427-1440.

Battersby, J., \& McLachlan, M. (2013). Urban food insecurity: A neglected public health challenge. South African Medical Journal, 103(10), 716-717.

Bennett, M. K. (1954). The World's food. New York: Harper and Brothers.

Björk, S. (2004). Economical aspects of diabetes care. Global Forum For Health Research Forum 8 (Mexico City, November 2004).

Bouis, H. E., \& Haddad, L. J. (1992). Are estimates of calorie-income elasticities too high? A recalibration of the plausible range. Journal of Development Economics, 39(2), 333-364.

Bourne, L. T., Lambert, E. V., \& Steyn, K. (2002). Where does the black population of South Africa stand on the nutrition transition? Public Health Nutrition, 5(1a), $157-162$.

Bravata, D. M., Sanders, L., Huang, J., Krumholz, H. M., Olkin, I., Gardner, C. D., \& Bravata, D. M. (2003). Efficacy and safety of low-carbohydrate diets: A systematic review. JAMA, 289(14), 1837-1850.

Briggs, A. D., Wolstenholme, J., Blakely, T., \& Scarborough, P. (2016). Choosing an epidemiological model structure for the economic evaluation of non-communicable disease public health interventions. Population Health Metrics, 14(1), 17. http://dx. doi.org/10.1186/s12963-016-0085.

Brown, E. M., Wlodarska, M., Willing, B. P., Vonaesch, P., Han, J., Reynolds, L. A., ... Borchers, C. H. (2015). Diet and specific microbial exposure trigger features of environmental enteropathy in a novel murine model. Nature Communications, 6. http:// dx.doi.org/10.1038/ncomms8806.

Brownell, K. D., \& Frieden, T. R. (2009). Ounces of prevention-The public policy case for taxes on sugared beverages. New England Journal of Medicine, 360(18), 1805-1808.

Brown, L. R., Feldstein, H. S., Haddad, L., \& Peña, C. (1995). Women: The key to food security. Washington, DC: International Food Policy Research Institute.

Burchi, F., \& De Muro, P. (2016). From food availability to nutritional capabilities: Advancing food security analysis. Food Policy, 60, 10-19.

CFS (2012). Coming to terms with terminology. Rome, Italy: Committee on World Food Security, Thirty-ninth Session, 15-20 (October 2012, Retrieved from http://www. fao.org/docrep/meeting/026/MD776E.pdf, 07 March, 2017).

Chambers, R., \& von Medeazza, G. (2014). Reframing under-nutrition: Faecally-transmitted infections and the 5 as, IDS working paper 450. Brighton: Institute for Development Studies.

Chauvin, N. D., Mulangu, F., \& Porto, G. (2012). Food production and consumption trends in sub-Saharan Africa: Prospects for the transformation of the agricultural sector. UNDP Working Paper, WP 2012-011 (retrieved from http://www.africa.undp.org/ content/rba/en/home/library/working-papers/food-production-consumptiontrends.html, 31 March, 2017).

Claro, R. M., \& Monteiro, C. A. (2010). Family income, food prices, and household purchases of fruits and vegetables in Brazil. Revista Saúde Pública, 44(6).

Cristancho, S., \& Vining, J. (2004). Culturally defined keystone species. Human Ecology Review, 11(2), 153-164.

Darmon, N., \& Drewnowski, A. (2015). Contribution of food prices and diet cost to socioeconomic disparities in diet quality and health: A systematic review and analysis. Nutrition Reviews, 73(10), 643-660. http://dx.doi.org/10.1093/nutrit/nuv027.

Devereux, S., \& Waidler, J. (2017). Why does malnutrition persist in South Africa despite social grants? Centre of excellence in food security, working paper 1 (Retrieved from http://foodsecurity.ac.za/working-papers, 31 March, 2017).

Dobbs, R., \& Manyika, J. (2015). The obesity crisis: How to fight a scourge as damaging to the global economy as war. The Cairo review of global affairs (05/05/2015, accessed from https://cdn.thecairoreview.com/wp-content/uploads/2015/09/CR18-DobbsManyika.pdf, 31 March, 2017).

Drimie, S., Gillespie, S., Jere, P., \& Msuya, J. (2010). Right to food: HIV and food price increases. Human Rights, 37(1), 22-25.

FAO, IFAD \& WFP (2015). The state of food insecurity in the world 2015: Meeting the 2015 international hunger targets: Taking stock of uneven progress. Rome: Food and Agriculture Organization (Retrieved from http://www.fao.org/3/a-i4646e.pdf, 31 March, 2017).

FAO (2002). The developing world's new burden: Obesity. Rome: Food and Agriculture Organization (Retrieved from http://www.fao.org/Focus/E/obesity/obes1.htm, 31 March, 2017).

FAO (2010). Sustainable diets and biodiversity directions and solutions for policy, research and action. Rome: Food and Agriculture Organization (Retrieved from http://www.fao. org/docrep/016/i3004e/i3004e00.htm, 31 March, 2017).

FAO (2012). World agriculture towards 2030/2050: the 2012 revision (no. 12-03, p. 4). Rome, Food and Agriculture Organization, Rome: ESA Working paper.

FAO (2015). Regional overview of food insecurity in Africa African food security: Prospects brighter than ever. Food and Agriculture Organization (Retrieved from 04/02/16 from http://www.fao.org/3/a-i4635e.pdf).

Fayemi, P. O., Muchenje, V., Yetim, H., \& Abdulatef, A. (2016). Targeting the pains of food insecurity and malnutrition among internally displaced persons with nutrient synergy and analgesics in organ meat. Food Research International (article in press, doi: http://dx.doi.org/10.1016/j.foodres.2016.11.038).
Foster, J. A., Krone, S. M., \& Forney, L. J. (2008). Application of ecological network theory to the human microbiome. Interdisciplinary perspectives on infectious diseases.

Frayne, B., Pendleton, W., Crush, J., Acquah, B., Battersby-Lennard, J., Bras, E., Leduka, C. (2010). The state of urban food insecurity in southern Africa. Urban food security series, 2. Kingston and Cape Town: Queen's University and AFSUN.

Frenk, J., \& Gómez-Dantés, O. (2011). The triple burden: Disease in developing nations. Harvard International Review, 33(3), 36.

Gandhi, V. P., \& Zhou, Z. (2014). Food demand and the food security challenge with rapid economic growth in the emerging economies of India and China. Food Research International, 63, 108-124.

Godfray, H. C. J., Beddington, J. R., Crute, I. R., Haddad, L., Lawrence, D., Muir, J. F., Toulmin, C. (2010). Food security: The challenge of feeding 9 billion people. Science, 327(5967), 812-818.

Gómez, M. I., \& Ricketts, K. D. (2013). Food value chain transformations in developing countries: Selected hypotheses on nutritional implications. Food Policy, 42, 139-150.

Government of South Africa (2016). Budget speech 2016. Pretoria: RSA (Retrieved from: http://www.treasury.gov.za/documents/national\%20budget/2016/speech/speech. pdf, 18 May, 2017).

Green, K., \& Foster, C. (2005). Give peas a chance: Transformations in food consumption and production systems. Technological Forecasting and Social Change, 72(6), 663-679.

Haddad, L., Alderman, H., Appleton, S., Song, L., \& Yohannes, Y. (2003). Reducing child malnutrition: How far does income growth take us? World Bank Economic Review, 17(1), 107-131.

Haddad, L., \& Kanbur, R. (1990). How serious is the neglect of intra-household inequality? The Economic Journal, 100(402), 866-881.

Haggblade, S., Duodu, K. G., Kabasa, J. D., Minnaar, A., Ojijo, N. K., \& Taylor, J. R. (2016). Emerging early actions to bend the curve in sub-Saharan Africa's nutrition transition. Food and Nutrition Bulletin, 37(2), 219-241.

Haregu, T. N. (2012). Epidemiology, complications and management of diabetes in Ethiopia: A systematic review. Journal of Diabetes, 4(2), 174-180.

Hawkes, C. (2006). Uneven dietary development: Linking the policies and processes of globalization with the nutrition transition, obesity and diet-related chronic diseases. Globalization and Health, 2, 4-22.

Hofman, K. J., \& Tollman, S. M. (2013). Population health in South Africa: A view from the salt mines. The Lancet Global Health, 1(2), e66-e67.

Hulme, D., \& Shepherd, A. (2003). Conceptualizing chronic poverty. World Development, 31(3), 403-423.

Hutton, G., \& Haller, L. (2004). Evaluation of the costs and benefits of water and sanitation improvements at the global level. Geneva: water sanitation and health protection of the human environment. World Health Organization, 2004.

IAASTD (2009). Agriculture at a crossroads: the global report, international assessment of agricultural knowledge. Science and Technology for Development. Island Press.

Iansiti, M., \& Levien, R. (2004). Strategy as ecology. Harvard Business Review, 82(3), 68-81.

IDF (2015). IDF Diabetes Atlas (7th Edition). International Diabetes Federation (Retrieved from http://www.diabetesatlas.org/ on 04 February, 2016).

IFPRI (2016). Global Food Policy Report - 2016. Washington, DC: International Food Policy Research Institute (Retrieved from http://www.ifpri.org/publication/2016-globalfood-policy-report, 31 March, 2017).

Igumbor, E. U., Sanders, D., Puoane, T. R., Tsolekile, L., Schwarz, C., Purdy, C., Hawkes, C. (2012). "Big food," the consumer food environment, health, and the policy response in South Africa. PLoS Medicine, 9(7), e1001253.

Jerven, M. (2013). Poor numbers: How we are misled by African development statistics and what to do about it. Ithaca: Cornell University Press.

Kay, C. (2014). KFC follows Nigerian fast food pioneer in African growth. Retrieved from http://www.bloomberg.com/news/articles/2014-03-27/kfc-follows-nigerian-fastfood-pioneer-in-african-growth, 05 February, 2016.

Kearney, J. (2010). Food consumption trends and drivers. Philosophical Transactions of the Royal Society B: Biological Sciences, 365(1554), 2793-2807.

Kelly, T., Yang, W., Chen, C. S., Reynolds, K., \& He, J. (2008). Global burden of obesity in 2005 and projections to 2030. International Journal of Obesity, 32(9), 1431-1437.

Kimenju, S. C., Rischke, R., Klasen, S., \& Qaim, M. (2015). Do supermarkets contribute to the obesity pandemic in developing countries? Public Health Nutrition, 18(17), 3224-3233. http://dx.doi.org/10.1017/S1368980015000919.

Kotliar, N. B. (2000). Application of the new keystone-species concept to prairie dogs: How well does it work? Conservation Biology, 14(6), 1715-1721.

Kuhlmann, M. (2009). Patterns of diversity, endemism and distribution of bees (Insecta: Hymenoptera: Anthophila) in southern Africa. South African Journal of Botany, 75(4), 726-738.

Legatum Institute (2016). The African prosperity report. London: Legatum Limited (Retrieved from http://media.prosperity.com/2016/pdf/2016-AfricaReport-web.pdf, 31 March, 2017).

Mars, M. M., Bronstein, J. L., \& Lusch, R. F. (2012). The value of a metaphor: Organizations and ecosystems. Organizational Dynamics, 41(4), 271-280.

Mbewu, A., \& Mbanya, J. C. (2006). Cardiovascular disease. In D. T. Jamison, R. G. Feachem, \& M. W. Makgoba (Eds.), Disease and mortality in sub-Saharan Africa. Washington, DC: World Bank.

Melo, P. C., Abdul-Salam, Y., Roberts, D., Gilbert, A., Matthews, R., Colen, L., ... Paloma, S. G. Y. (2015). Income elasticities of food demand in Africa: A meta-analysis (no. JRC98812). Joint Research Centre: Institute for Prospective and Technological Studies.

Mills, L. S., Soule, M. E., \& Doak, D. F. (1993). The keystone-species concept in ecology and conservation. Bioscience, 43(4), 219-224.

Mo Ibrahim Foundation (2015). African urban dynamics: Facts and figures. (Retrieved from http://mo.ibrahim.foundation/forum/year/2015/, 31 March, 2017).

Mocumbi, A. O. (2012). Lack of focus on cardiovascular disease in sub-Saharan Africa. 
Cardiovascular Diagnosis and Therapy, 2(1), 74-77.

Muchenje, V., \& Mukumbo, F. E. (2015). Introduction to the special issue food and nutrition security: Can science and good governance deliver dinner? Food Research International, 76, 879-881.

Muhammad, A., Seale, J. L., Meade, B., \& Regmi, A. (2011). International evidence on food consumption patterns: An update using 2005 international comparison program data. USDA-ERS Technical Bulletin No. 1929 (Retrieved from https://papers.ssrn.com/ sol3/papers.cfm?abstract_id = 2114337, 17 June, 2017).

Nakamura, S., Harati, R., Lall, S. V., Dikhanov, Y., Hamadeh, N., Oliver, W. V., ... Yamanaka, M. (2016). Is living in African cities expensive? World Bank policy research working paper no. 7641 (Retrieved from from https://ssrn.com/abstract $=2765252$, 23 May, 2017).

Narayan, D., Chambers, R., Kaul Shah, M., \& Petesch, P. (2000). Voices of the poor: Crying out for change. New York: Oxford University Press for the World Bank.

Ncube, M., Lufumpa, C. L., \& Kayizzi-Mugerwa, S. (2011). The middle of the pyramid: dynamics of the middle class in Africa. Chief Economist Complex, Market Brief, April 20Tunis: African Development Bank (Retrieved from https://www.afdb.org/en/ documents/document/market-brief-the-middle-of-the-pyramid-dynamics-of-themiddle-class-in-africa-23582/, 31 March, 2017).

Ng, M., Fleming, T., Robinson, M., Thomson, B., Graetz, N., Margono, C., ... Abraham, J. P. (2014). Global, regional, and national prevalence of overweight and obesity in children and adults during 1980-2013: A systematic analysis for the global burden of disease study 2013. The Lancet, 384(9945), 766-781.

Neil, R., Rulof, B., Wicus, C., \& Friedrich, K. (2015). Income and price elasticities of demand in South Africa: An application of the linear expenditure system (no. UNU-WIDER research paper wp2015-100).

Opie, L. H., \& Mayosi, B. M. (2005). Cardiovascular disease in sub-Saharan Africa Circulation, 112, 3536-3540.

Österblom, H., Jouffray, J. B., Folke, C., Crona, B., Troell, M., Merrie, A., \& Rockström, J. (2015). Transnational corporations as 'keystone actors' in marine ecosystems. PloS One, 10(5), e0127533.

Øyen, E. (2002). Poverty production: A different approach to poverty understanding. (Retrieved from http://bora.uib.no/bitstream/handle/1956/2454/ Poverty_production.pdf;sequence $=1,27$ May 2017) .

Paillard, S., Treyer, S., \& Dorin, B. (2014). Agrimonde: Scenarios and challenges for feeding the world in 2050. Vancouver: Springer Science \& Business Media.

Paine, R. T. (1995). Conversation on refining the concept of keystone species. Conservation Biology, 9(4), 962-964.

Pingali, P. (2007). Westernization of Asian diets and the transformation of food systems: Implications for research and policy. Food Policy, 32(3), 281-298.

Pinstrup-Andersen, P. (2007). Agricultural research and policy for better health and nutrition in developing countries: A food systems approach. Agricultural Economics, 37(s1), 187-198.

Pollan, M. (2008). In defense of food: An eater's manifesto. London: Penguin.

Popkin, B. M. (1999). Urbanization, lifestyle changes and the nutrition transition. World Development, 27(11), 1905-1916.

Popkin, B. M. (2001). The nutrition transition and obesity in the developing world. The Journal of Nutrition, 131(3), 871S-873S.

Popkin, B. M. (2003). The nutrition transition in the developing world. Development Policy Review, 21(5), 581-597.

Popkin, B. M., \& Gordon-Larsen, P. (2004). The nutrition transition: Worldwide obesity dynamics and their determinants. International Journal of Obesity, 28, S2-S9.

Popkin, B. M., Horton, S., Kim, S., Mahal, A., \& Shuigao, J. (2001). Trends in diet, nutritional status, and diet-related noncommunicable diseases in China and India: The economic costs of the nutrition transition. Nutrition Reviews, 59(12), 379-390.

Potts, D. (2013). Urban economies, urban livelihoods and natural resource-based economic growth in sub-Saharan Africa: The constraints of a liberalized world economy. Local Economy, 28(2), 170-187.

Rao, M., Afshin, A., Singh, G., \& Mozaffarian, D. (2013). Do healthier foods and diet patterns cost more than less healthy options? A systematic review and meta-analysis. BMJ Open, 3(12), e004277.

Ravallion, M. (2003). The debate on globalization, poverty and inequality: Why measurement matters. International Affairs, 79(4), 739-753.

Rocha, C. (2007). Food insecurity as market failure: a contribution from economics. Journal of Hunger \& Environmental Nutrition, 1(4), 5-22.

Rosen, S., Thome, K., \& Meade, B. (2016). Food security of developing countries expected to improve through 2026 as food prices fall and incomes rise. United States Department of Agriculture (Retrieved from https://www.ers.usda.gov/amber-waves/2016/june/ food-security-of-developing-countries-expected-to-improve-through-2026-as-foodprices-fall-and-incomes-rise/, 11 February, 2017).

Ruel, M. T., Minot, N., \& Smith, L. (2005). Patterns and determinants of fruit and vegetable consumption in sub-Saharan Africa: a multicountry comparison. Geneva: WHO/ Washington: IFPRI (Retreived from http://www.who.int/dietphysicalactivity/ publications/f\&v_africa_economics.pdf?ua =1, 16 June, 2017).

Ruel, M. T., Garrett, J. L., Hawkes, C., \& Cohen, M. J. (2010). The food, fuel, and financial crises affect the urban and rural poor disproportionately: A review of the evidence. Journal of Nutrition, 140(1), 170S-176S.

Saaty, T. L., \& Kearns, K. P. (1985). Analytical planning: The organization of systems, international series in modern applied mathematics and computer science. Vol. 7. Oxford: Pergamon Press.

Santeramo, F. G. (2015a). On the composite indicators for food security: Decisions matter!. Food Research International, 31(1), 63-73.

Santeramo, F. G. (2015b). Food security composite indices: Implications for policy and practice. Development in Practice, 25(4), 594-600.
Santeramo, F. G., \& Shabnam, N. (2015c). The income-elasticity of calories, macro-and micro-nutrients: What is the literature telling us? Food Research International, 76, 932-937.

Sheeran, J. (2012). Annual Martin J. Forman lecture 22 December, 2012. (Retrieved from http://www.ifpri.org/blog/are-we-headed-food-cliff, 16 January, 2015).

Schoenaker, D. A., Mishra, G. D., Callaway, L. K., \& Soedamah-Muthu, S. S. (2016). The role of energy, nutrients, foods, and dietary patterns in the development of gestational diabetes mellitus: A systematic review of observational studies. Diabetes Care, 39(1), 16-23.

Sen, A. K. (1980). Equality of what? In S. M. McMurrin (Ed.), The Tanner lectures on human value (pp. 195-220). Salt Lake City: University of Utah Press.

Sen, A. K. (1983). Poor, relatively speaking. Oxford Economic Papers, 35, 153-169.

Sobal, J., Kettel Khan, L., \& Bisogni, C. (1998). A conceptual model of the food and nutrition system. Social Science and Medicine, 47(7), 853-863.

Stats, S. A. (2012). Income and expenditure of households, 2010/2011. Statistics South Africa. Pretoria: Statistics South Africa.

Stats, S. A. (2017). South African demographic and health survey: Key indicators report. Pretoria: Statistics South Africa.

Subramanian, S., \& Deaton, A. (1996). The demand for food and calories. Journal of Political Economy, 104, 133-162.

Swinburn, B., Egger, G., \& Raza, F. (1999). Dissecting obesogenic environments: The development and application of a framework for identifying and prioritizing environmental interventions for obesity. Preventive Medicine, 29, 563-570.

Tantchou Tchoumi, J. C., \& Butera, G. (2013). Profile of cardiac disease in Cameroon and impact on health care services. Cardiovascular Diagnosis and Therapy, 3(4), 236-243.

Timmer, C. P. (1988). The agricultural transformation. In H. B. Chenery, \& T. N. Srinivasan (Vol. Eds.), Handbook of development economics. Vol. 1. Amsterdam: North Holland.

Timmer, C. P., Falcon, W. P., \& Pearson, S. R. (1983). Food policy analysis, Baltimore. Chicago: Johns Hopkins University Press.

Tirado, M. C., Clarke, R., Jaykus, L. A., McQuatters-Gollop, A., \& Frank, J. M. (2010). Climate change and food safety: A review. Food Research International, 43(7), 1745-1765.

Tschirley, D., Reardon, T., Dolislager, M., \& Snyder, J. (2015). The rise of a middle class in east and southern Africa: Implications for food system transformation. Journal of International Development, 27(5), 628-646.

UN-HABITAT (2014). The state of African cities 2014: Re-imagining sustainable urban transitions. Nairobi: United Nations Human Settlements Program.

UNDESA (2014). World Urbanization Prospects: The 2014 revision, United Nations, Department of Economic and Social Affairs, Population Division, Highlights (ST/ESA/ SER.A/352).

UNDESA (2015a). World Population Prospects: The 2015 Revision, Key Findings and Advance Tables. United Nations, Department of Economic and Social Affairs, Population Division, Working Paper No. ESA/P/WP.241.

UNDESA (2015b). Probabilistic Population Projections based on the World Population Prospects: The 2015 Revision. Population Division, United Nations, Department of Economic and Social Affairs, Population Division. (Retrieved from http://esa.un.org/ unpd/ppp/, 31 March, 2017).

UNEP (2010). Africa Water Atlas. Division of early warning and assessment. Nairobi, Kenya: United Nations Environment Programme.

van Dijk, M., \& Meijerink, G. W. (2014). A review of global food security scenario and assessment studies: Results, gaps and research priorities. Global Food Security. http:// dx.doi.org/10.1016/j.gfs.2014.09.004i.

Vincent, H. K., Vincent, K. R., \& Lamb, K. M. (2010). Obesity and mobility disability in the older adult. Obesity Reviews, 11(8), 568-579.

von Bertalanffy, L. (1968). General systems theory. New York: George Braziller.

Vukmirovic, M. (2015). The effects of food advertising on food-related behaviours and perceptions in adults: A review. Food Research International, 75, 13-19.

WDI (2016). The World Development Indicators for 2014 updated on 10 August 2016. (Retrieved from http://data.worldbank.org/data-catalog/world-developmentindicators, 13 August, 2016).

Webb, P., Coates, J., Frongillo, E. A., Lorge Rogers, B., Swindale, A., \& Bilinsky, P. (2006). Measuring household food insecurity: Why it's so important and yet so difficult to do. Journal of Nutrition, 136, 1404S-1408S.

WHO \& UNICEF (2014). Progress on sanitation and drinking-water - 2014 update. Geneva: World Health Organization and UNICEF (Retrieved from https://www.unicef.org/ gambia/Progress_on_drinking_water_and_sanitation_2014_update.pdf, 31 March, 2017).

WHO (2014). The health of the people: what works - the African Regional Health Report 2014. Geneva: World Health Organization (Retrieved from https://www.aho.afro.who.int/ en/publication/1801/african-regional-health-report-2014-health-statistics, 31 March, 2017).

Wild, S., Roglic, G., Green, A., Sicree, R., \& King, H. (2004). Global prevalence of diabetes: Estimates for the year 2000 and projections for 2030. Diabetes Care, 7, 1047-1053.

Wittman, H. K. (2010). Reconnecting agriculture and the environment: food sovereignty and the agrarian basis of ecological citizenship. In H. K. Wittman, A. Desmarais, \& N. Wiebe (Eds.), Food sovereignty: reconnecting food, nature and community. Canada: Fernwood Publishing.

Ze, X., Duncan, S. H., Louis, P., \& Flint, H. J. (2012). Ruminococcus bromii is a keystone species for the degradation of resistant starch in the human colon. The ISME Journal, 6(8), 1535-1543.

Zhou, Y., \& Staatz, J. (2016). Projected demand and supply for various foods in West Africa: Implications for investments and food policy. Food Policy, 61, 198-212. 